\title{
Post-Conflict Passageway Opportunities in the South Caucasus and Georgian Domination Perspectives
}

\author{
Davit Shatakishvili, MPA \\ Shatakishvili95@gmail.com \\ Tbilisi State University, Faculty of Economics and Business Administration, 0186, Tbilisi, Georgia
}

\begin{abstract}
The global pandemic crisis in 2020 was followed by a military conflict in the South Caucasus. Along with exacerbating regional threats and the economic recession, the confrontation has significantly altered the pre-existing geopolitical situation in the region. These processes have led regional actors to strengthen strategic positions, as well as the new transport and trade opportunities have emerged. The aim of the paper is to review the stand-off results and the regional postures of the countries in the light of the changed circumstances. Additionally, the study evaluates the potential of the South Caucasus New Transit Road, neighborhood interests and prospective threats for Georgia to lose its dominance as a regional transit hegemon. Furthermore, the article analyzes the role of Georgia in regional conveyance and discusses the factors that will help the country increase its national competitiveness. It is crucial to see and analyze the existing affairs from a wide angle, in order to make future reasonable decisions.
\end{abstract}

Keywords: Regional Trade; South Caucasus; Infrastructure; Energy; Transport

\section{Political Status Quo}

After November 9, 2020, the geopolitical reality in the South Caucasus has dramatically changed. The second Karabakh war (September 27 - November 9, 2020) was completed, that killed hundreds of people, but the conflict is not over yet. The ceasefire agreement has been assessed differently by the parties, although one thing is clear. From the new regional crisis, Russian Federation benefited the most, as it further strengthened its position in the region. This will certainly have long-term economic and political consequences. Russia has deployed up to 2,000 troops in the conflict zone, and consequently, gained more leverage over the countries in the South Caucasus. Russian troops will control the road from Armenia to Karabakh, as well as the road on the territory of Armenia, which connects Azerbaijan with Nakhichevan (Ringler, 2020). The first rotation of Russian armed forces expires in 2025, after which Russia will try to extend its mission at least for one more term. According to the current examples, Russia has not leaved the places yet, where it has deployed the soldiery for the same reason as in Karabakh.

In addition to military purposes in the region, Russian forced bases pursue other interests, such as strengthening Russian influence, spreading their ideology and supporting separatism. This is accompanied by the fruitful work of Russian media propaganda machines, which ultimately creates the desired picture for them. Later it is used as for political, as well as social and economic purposes. By strengthening its military positions, Russia has further reinforced its domination in both Armenia and Azerbaijan. Therefore, both will have to pursue more Russian interests than has been the case so far. For Russia, it is also a good lever to have more influence on Armenia's European aspirations and to some extent force this vector to be changed. In any internal state and regional context, both countries will have to take more into account and envisage Russia's interests and directives. 


\section{New Transit Opportunities in the South Caucasus}

Along with the new geopolitical reality, renewed economic issues have also become the subject of broad discussion. We are talking about the restoration of the transport corridor from Azerbaijan to Armenia via Nakhichevan Autonomous Republic. Some experts assume, that this project will call into question the status of Georgia as a leading transit passageway in the region. According to the Azerbaijani experts, construction of the new railway line will allow Azerbaijan to connect with Europe in more diverse ways, which will free the country from excessive dependence on Georgia, despite the calm and stable bilateral relations. They also explain that the new land connections will guarantee more peace and economic stability in the region. Some of them also suppose that the role of the Baku-Tbilisi-Kars railway could suffer significantly if Azerbaijan appears to have a more economically viable and efficient transit corridor. In addition, Iran, which will get a possibility to have a direct line with Russia, also benefits significantly. However, at the same time, the number of cargos coming from Azerbaijan will importantly be reduced.

In January this year, the presidents of Russia, Armenia and Azerbaijan signed an agreement to restore rail and road traffic and strengthen cooperation between the three countries. However, except for the signatory parties, other countries of the neighborhood seek for their benefit. For instance, Turkey will get a possibility to directly access Azerbaijan, without using the roads of Iran and Georgia. Besides, in a long-term perspective Turkey gets an opportunity to have an access to the Caspian Sea and more flexibly connect the Central Asia countries. Nakhichevan road also makes a good promise for Russia to create alternative corridors to the regional countries and middle east (Baghirov, 2021).

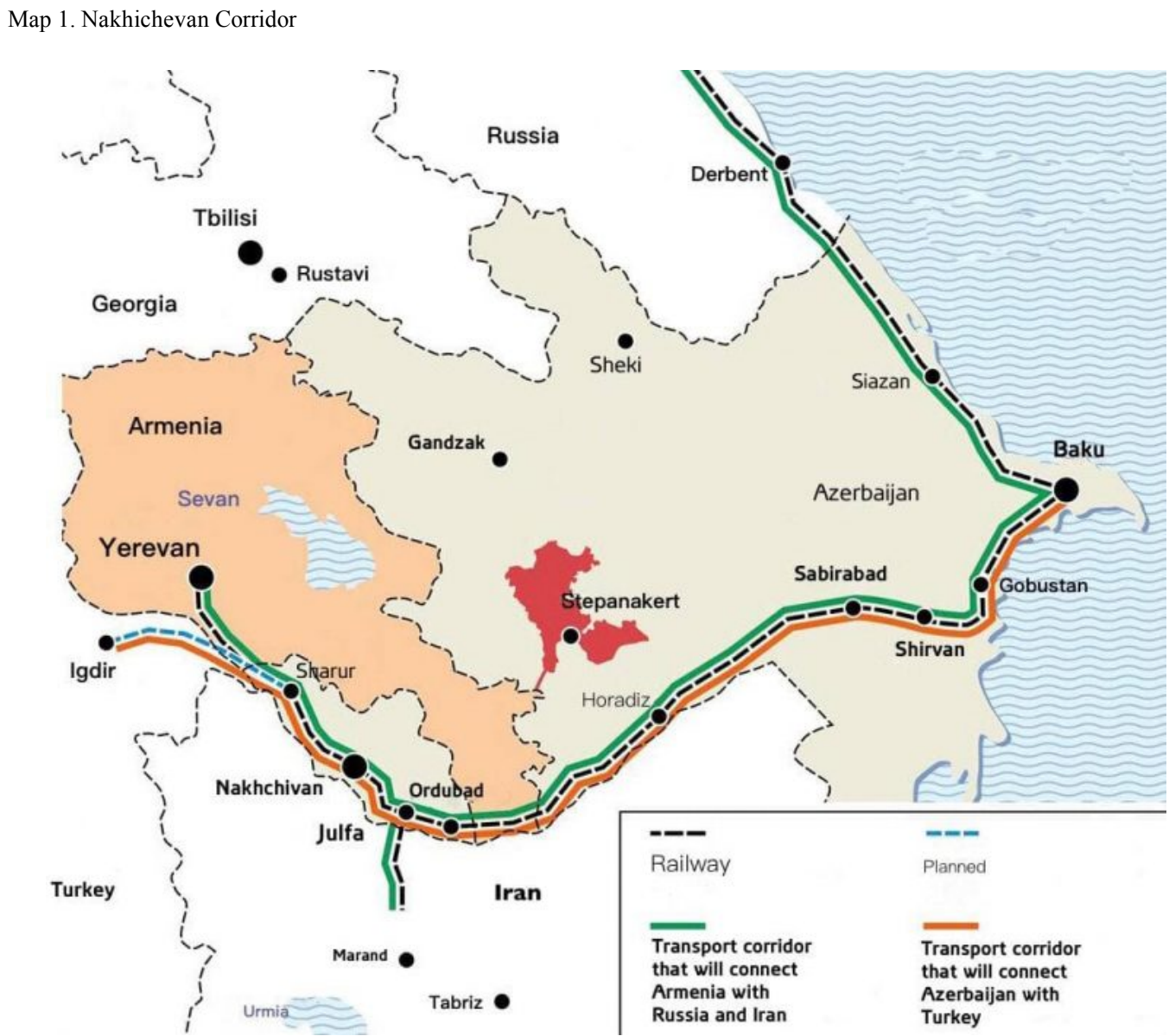

Source: South Front 
Though, the implementation of the project is associated with quite large finances. A study, carried out by International Alert in 2014, estimated the rehabilitation costs for the east-west corridor. The cost for Azerbaijani section is approximately 277 million, Armenian section - 105 million and the Turkish section - 52 million US dollars (International Alert, 2014). Whereas, the most recent calculation by the "South Caucasus Railway Company" (Russian-owned institution, that controls major railways in Armenia) says that the restoration of the mentioned sections will cost the Armenian side about 210 million dollars. Another $110 \mathrm{~km}$ of railway will have to be restored in Azerbaijan. According to preliminary estimates, this will cost 400450 million dollars (Harutyunyan, 2021).

Actually, this railway was built in 1941, and the Russian Federation was connected not only with Armenia and Azerbaijan, but also with the Islamic Republic of Iran and through it to the Middle East (O'Byrne, 2021). Therefore, restoring its functioning is in Russia's direct interest. At the same time, it is likely that Azerbaijan will receive financial and political assistance from the involved partners, as it is in their interests to develop regional trade in faster and cheaper ways. These parties seem to have high hopes for the new freight corridor project. In addition to cargo, the Azerbaijani side also has high hopes for natural gas transportation. It wants to edge away Iran, which receives a commission of $15 \%$ of its transported gas, under the 2004 agreement (Huseynov, 2021).

Nakhichevan transit network also offers new opportunities to the Armenian side. With stronger ties between Russia and Armenia, this project may be a guarantee of closer proximity to the North for Armenia and consequently they expect a change for the better regarding to the economy. This is what the Prime Minister of Armenia, Nikol Pashinyan, says, that involvement in regional transport networks will be the beginning of new trading possibilities for the Armenian economy.

It is unlikely that Armenia will be so comfortable relying on Azerbaijan to connect with Russia, which of course carries other additional risks. Currently, Armenia is connected to the Russian Federation via the Georgian highway, through the Upper Larsi checkpoint.

The restoration of the railway will allow Armenia to be connected with Russia for the first time by rail lines since the 1990 s. Additionally, Soviet railway reconstruction will help Armenia not only in terms of economic growth, but also will positively strengthen its regional and geopolitical positions. Moreover, the project will allow Armenia to avoid other additional costs related to the development of the transit infrastructure (O’Byrne, 2021).

In recent years, the issue of a railway line through the occupied region of Georgia, Abkhazia, has been raised several times, which would connect Armenia and Russia by the shortest route, has been opposed by the Georgian side. The initiative came from representatives of the de-facto government of Abkhazia, who demand the involvement of Abkhazia in the RussianArmenian railway project. The project certainly has the interests of both Russia and Armenia as well as Iran, but participation in this cooperation is neither politically nor economically profitable for Georgia. Furthermore, this project may even be detrimental for Georgia, as cargo from Russia to Armenia will bypass Georgian ports and reduce road shipments. Leaving aside political and economic factors, experts estimate that the construction of the railway will cost about \$ 300 million US dollars, with vague prospects, and it is interesting to see who is worth to pay this money.

Presently and probably in the future as well, Armenia does not see other alternatives to a railway connection with Russia, so it will be rational decision to agree to the project and after several decades of isolation get involved in regional projects.

On the other hand, it is worth considering how much Azerbaijan will lead its energy resources and transport railway with a state at a war condition. This directly means the seizure of state importance objects for the opponent. Of course, this corridor, due to its scale, will not be able to carry cargo for the whole Caucasus, but it will play a role to some extent, which may 
weaken Georgia's transit function, but not its leadership. Due to the reason, that besides Azerbaijan and Armenia, other regional actors rely on the benefiting from the project and the economic interest is multilateral, it is unlikely that either side would be interested in escalating the situation.

\section{Energy Projects through Georgia}

In the modern world, a stable energy environment and supply channels are inherently significant. Over the years, Georgia has played a vital role in the region as a reliable and stable energy carrier. Particularly, in recent decades, significant sums of money have been spent on building and developing the country's energy infrastructure, therefore, in this direction the country remains a regional leader (Arghutashvili, 2021).

\subsection{Natural Gas Projects Via Georgia}

"South-Caucasian Pipeline" - system provides gas transportation from Shah Deniz field in Azerbaijan via Georgia to Erzurum in Turkey. Whole length of the pipeline is 692 kilometers, and Georgian section - 248 kilometers, conduction -6 Billion Cubic Meter/year. From this transit, Georgia receives natural gas at lower price, than it is on the market (British Petroleum Georgia, 2019).

"North-South Caucasus Main Pipeline" - provides gas transportation from Russia to Armenia. The pipeline starts from Georgia-Russian Border and continues down to the Georgian-Armenian border and its length is 253 kilometers, conduction - 2 Billion Cubic Meter/year. The pipeline is managed by "Georgian Gas Transport Company" (Ministry of Energy of Georgia, 2017).

TANAP - Project has already been implemented and provides natural gas transportation from Azerbaijan to Europe via Georgia and Turkey. This is the part of Trans-Adriatic Pipeline (TAP). TANAP project implementation is an essential part of energetic, economic, political security and stability of Georgia. According to the project, by 2023 the capacity of free natural gas received by Georgia will be quadruplicated than it is today and will be increased from 300 million cubic meter to 1.5 billion cubic meters. 16 billion cubic meter natural gas will be transited annually, but as it is supposed by 2026 , transit volume should be increased up to 30 billion cubic meters in order for Georgia to receive $5 \%$ of the transited natural gas.

Map 2. Natural Gas Transit through Georgia

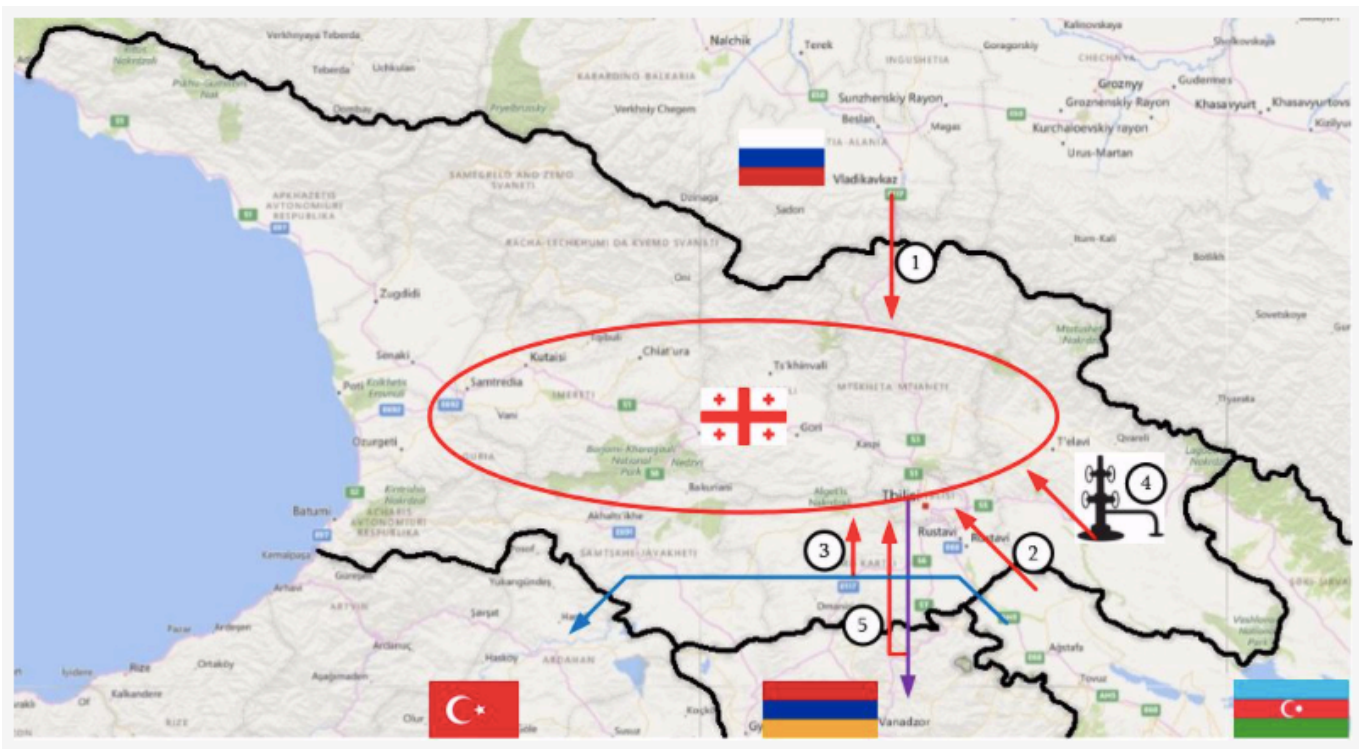




\subsection{Oil Transportation Projects via Georgia}

"Baku-Tbilisi-Ceyhan Pipeline" - traverses three countries: Azerbaijan, Georgia and Turkey, from Caspian to Mediterranean Sea and provides oil transportation from Azerbaijan to Ceyhan Marine Terminal of Turkey. Its length is 1768 Kilometers and conduction - 50 Million Barrel/year. This project has a huge regional meaning, since Caspian Sea was connected to the Mediterranean Sea, bypassing the Bosporus Strait. From this project Georgia gets a direct economic benefit, as a transit tax on every barrel of oil transported (British Petroleum Georgia, 2019).

"Western Route Export Pipeline" - In Georgia known as "Baku-Supsa Pipeline", has been functioning since 1999 and it is the first investment of international energy company BP in Georgia. Annual conduction is 7 million tons/year. This pipeline provides oil transportation to Supsa terminal from Shiraz Gas field, via Sangachal terminal. Western Route Export Pipeline project is evaluated as a guarantee of stability and peace in the south Caucasus region (Eisa Shipping Agencies, 2012).

\subsection{Transport Projects via Georgia}

"Baku-Tbilisi-Kars" - is a world-class importance projects, that connects Asian and European continents. The project, which was launched in 2017 and had a budget of $\$ 775$ million, has made it possible for Europe to have better access to markets such as China, India, Central Asia and the South Caucasus.

In addition, through Georgia, Armenia is connected to the Russian Federation by the Larsi checkpoint. Other countries in the region also get benefit from the same road.

The new geopolitical reality will not lead to significant changes in terms of energy. The past years have shown that Georgia performs the functions of the energy corridor without interruptions, which is important for the stability of the region (Coffey, 2021). In this regards Georgia remains as an important pillar. However, this does not allow the country to relax. Even more, it is necessary to attract more foreign direct investments and implement new infrastructure projects, which will ensure the long-term sustainability and stability of the country.

\section{Conclusion}

Despite the significant changes in the South Caucasus, Georgia still remains and will endure a major transit artery in the region, and new projects are unlikely to cause significant damage to it, for the following reasons:

- Hundreds of millions of dollars have been invested in developing Georgia as a regional passageway over the years. In addition to the financial factors, the trust and credibility, that has been established over the decades in the neighborhood is crucial. Apart from the Baku-Tbilisi-Kars railway and road infrastructure, which serves neighboring countries, Georgia is an important energy corridor. It is practically impossible to transfer all this so easily to someone else in the medium term;

- The new regional transit project, that includes new and rather large finances, is not as easy to be implemented as it seems at first glance. Along with the economic issues, political and security factors need to be considered, which, despite the agreement, still require extensive discussions and proper risk analysis;

- Into the bargain, in case of project implementation, the new railway is unlikely to handle most of the freight moving in the South Caucasus. In the long run it may become just an alternative corridor. The shortest way for Armenia to connect with Russia is through Georgia. On the one hand, the new road extends about $600 \mathrm{~km}$ to Russia, on the other hand, it is completely dependent on the Azerbaijani side to connect with the north; 
- If the project is implemented, it is improbable that the Azerbaijani side will use it to the extent that it will call into question Georgia's transit dominance. Most likely, this will be an alternative way, for which it will be difficult to replace the Georgian part. It is also unexpected, the large-scale energy projects to be implemented, since this means the interception of strategic resources in the hands of the contradictor, so this allows a space for possible manipulations. All this is accompanied by the risks of reactivation of the frozen conflict, which will call into question the sustainability of regional strategic projects;

- Furthermore, it is important that Georgia is the only stronghold in the region for both Europe and the United States. Therefore, the strong transit function of Georgia is in their direct interests, and it is likely that support in this regard will be further expanded.

However, here we can discuss the potential risks for Georgia. Reducing Georgia's role in the region's transport system has a negative impact on foreign direct investments. In addition, about 5\% of GDP comes from transit revenues, the reduction of which will be a significant loss for the economy of the country. All this will have an adverse influence on regional competitiveness, international positions and national security. Nevertheless, it should be underlined that the diversification of regional transport networks will contribute to the long-term political and economic sustainability of the region.

For example, in 2019, the export of Turkish products to Azerbaijan amounted to 1.65 billion dollars, the main part of which was carried out through the Georgian corridor. If this is diversified, it will certainly reduce Georgia's geopolitical weight, but it will not completely change it.

\section{Recommendations}

Against the background of the existing challenges, it is decisive for Georgia to increase its national competitiveness, which will further strengthen its regional positions and provide greater resilience to the external shocks. This requires attracting foreign investment and implementing infrastructure projects of strategic importance.

- Government has to provide special benefits for marine and aerial transportation companies to increase freight/passenger turnover and promote investments in strategic projects;

- Particular focus should be on customs tariffs and taxation policy in ports and railway;

- Government has to promote innovation companies and care about smart technology installation in transport sector;

- Partnership between public and private sector should be strengthened, that can be reflected in joint regional projects;

- It is strategically supreme to build a deep-water port in Anaklia, which would directly increase the country's competitiveness. In addition, continuous work is needed for greater integration into the world transport networks.

Ultimately, the new geopolitical climate in the region and the replay of countries' roles along with the threats brings new opportunities. It can be boldly said that in the medium-term perspective the new transit route will not cause significant damage to Georgia. However, in the long run, it is necessary for the country to implement all the projects of state importance that will serve its sustainability. The role of the transport corridor significantly determines the regional importance of Georgia and its international economic function. That is why it is crucial to monitor the ongoing processes constantly and make proactive decisions, which will avoid potential threats and complications for the country. 


\section{References}

Amiryan V., Baratelia B., Zade L., Hovsepyan K., Ibadoghlu G., Rasulov F., Charaia V. (2014). Rehabilitation of the railways in the South Caucasus: Assessment of the potential economic benefits. International Alert. Retrieved from https://www.internationalalert.org/sites/default/files/Caucasus RailwaysRehabilitationPt2 EN 2013.pdf

Arghutashvili V. (2021). Business Studies Issues in the Context of Regional Development Case in Georgia. Ekonomisti. Retrieved from https://www.researchgate.net/publication/351315133 BUSINESS STUDIES ISSUES IN THE CONTEXT OF REGIONAL DEVELOPMENT CAS E IN GEORGIA

Baghirov o. (2021). The Nakhchivan Corridor will boost connectivity in the Caucasus. Euractiv. Retrieved from https://www.euractiv.com/section/azerbaijan/opinion/the-nakhchivan-corridor-will-boost-connectivity-in-caucasus/

Baku-Tbilisi-Ceyhan Pipeline. (2019). British Petroleum Azerbaijan (BP). Retrieved from https:/www.bp.com/en az/azerbaijan/home/who-weare/operationsprojects/pipelines/btc.html

Coffey L. (2021). Georgia should not fear new transit routes in the South Caucasus. Peace, Prosperity, Partnership. Retrieved from https://www.mei.edu/publications/georgia-should-not-fear-new-transit-routes-south-caucasus

Energy Development Strategy of Georgia. (2017). Ministry of Energy of Georgia. Retrieved from http://energy.gov.ge/projects/pdf/pages/Sakartvelos\%20Energetikis\%20Ganvitarebis\%20Strategia\%2020172026\%20Bunebrivi\%20Gazis\%20Natsili\%201 637\%20geo.pdf

Harutyunyan A. (2021). The unblocking of the railway will cost about $\$ 210$ million. Retrieved from https:/hy.armradio.am/2021/03/26/tiplqupnınuuhil-

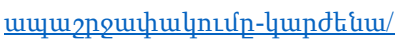

Huseynov V. (2021). Azerbaijan Embarks on Construction of Nakhchivan Railway (Part Three). The Jamestown Foundation. Retrieved from https://jamestown.org/program/azerbaijan-embarks-on-construction-of-nakhchivan-railway-part-three/

O’Byrne D. (2021). Nakhchivan rail plans promise to rewire Caucasus connections. Eurasianet. Retrieved from https://eurasianet.org/nakhchivan-rail-planspromise-to-rewire-caucasus-connections

Ringler N. (2020). The Armenia-Azerbaijan Ceasefire Terms: A Tenuous Hope for Peace. Justsecurity. Retrieved from https://www.justsecurity.org/73578/the-armenia-azerbaijan-ceasefire-terms-a-tenuous-hope-for-peace/

South Caucasus Pipeline Project. (2019). British Petroleum Georgia (BP). Retrieved from https://www.bp.com/en ge/georgia/home/who-we-are/scp.html

Supsa Oil Terminal. (2012). EISA Shipping Agencies. Retrieved from https://www.eisa.com.ge/port/supsa/ 